\title{
Pengembangan Desa Wisata Berkonsep Smart Tourism Melalui Pemberdayaan Kompetensi Masyarakat Desa Pujorahayu
}

\author{
Helmita $^{1 *}$, Oktavia Nila Sari ${ }^{2}$, Niluh Tiara Julianti ${ }^{1}$, Julpan Dwinata ${ }^{2}$ \\ 1. Fakultas Bisnis, Universitas Mitra Indonesia, Lampung, Indonesia \\ 2. Fakultas Komputer, Universitas Mitra Indonesia, Lampung, Indonesia \\ *email: mitahelmita@umitra.ac.id
}



\section{N F O A R T I K E L}

\section{Riwayat Artikel:}

Diterima: 28 Desember 2020

Direvisi: 31 Januari 2021

Dipublikasikan: 9 Februari 2021

Kata kunci:
Pengembangan, Smart Tourism,
Pemberdayaan, Masyarakat

\section{A B S T R A K}

Perubahan teknologi membuat wisatawan semakin cerdas, sadar dan melek teknologi, dari bidang pariwisata membuat persaingan yang sangat ketat sehingga memerlukan terobosan baru guna bertahan. Penelitian ini merupakan penelitian kualitatif dengan metode deskriptif. Tujuan penelitian ini adalah mengetahui pengembangan desa wisata berkonsep smart tourism melalui pemberdayaan masyarakat desa Pujo Rahayu, data diperoleh melalui melalui kajian literatur dari berbagai artikel jurnal, kuesioner, sebagai bahan perbandingan. Sampel yang digunakan adalah masyarakat lokal, kelompok sadar wisata, wisatawan sebanyak 98 orang dengan teknik purposive. Analisis yang digunakan meliputi uji validitas data, uji reliabilitas, uji normalitas, uji liniearitas, uji homogenitas, analisis regresi berganda, multikolinieritas, uji heteroskadasitas, uji otokorelasi, uji t, dan uji F. Hasil penelitian menunjukkan bahwa pengembangan desa wisata berkonsep smart tourism melalui pengembangan kompetensi masyarakat merupakah solusi bagi perkembangan sebuah desa. Selain itu pengaplikasian konsep smart tourism membuat sebuah pengalaman wisata yang baik, kesejahteraan masyarakat, meningkatkan efektifitas - daya saing - tujuan bisnis serta mengarah pada keberlanjutan yang kompetitif secara keseluruhan. 


\section{PENDAHULUAN}

Pariwisata merupakan salah satu sektor yang terus di kembangkan oleh pemerintah indonesia, karena indonesia di anugerahi begitu banyak keindahan Alam yang harus terus di kembangkan guna meningkatkan sektor perekonomian dan menjadi sumber pendapatan masyarakat sekitar tempat wisata, pariwisata merupakan sektor perekonomian yang tumbuh paling cepat diantara sektor - sektor lainnya. Sektor pariwisata merupakan unggulan menjadi kunci terpenting dalam pembangunan wilayah pada suatu negara serta peningkatan kesejahteraan bagi masyarakat.

Pengembangan pariwisata berbasis kemasyarakatan menjadi alternatif pariwisata berkelanjutan yang menekankan titik berat keterlibatan masyarakat secara aktif dalam mengembangkan sektor pariwisata. Pariwisata berbasis smart tourim merupakan ekosistem baru yang dapat mendukung dan memfasilitasi terciptanya inovasi baru yang berhubungan menggunakan pengaplikasian teknologi dan pengembangan pengalaman wisata cerdas. Pengembangan hubungan setara teknologi dan bidang pariwisata berdampak lahirnya konsep smart tourism. Smart tourism berfungsi menggambarkan situasi terbaru bagaimana pengembangan dalam bidang pariwisata serta telah di pengaruhi evolusi dari pesatnya perkembangan teknologi dan informasi. Pesatnya perkembangan teknologi dan informasi menjadi jembatan untuk menyatukan ussaha - usaha mikro dari masyarakat setempat dan nomanden yang ada kearah pasar global.

Pengembangan inovasi teknologi dan informasi merupakan konsep dari smart dalam smart tourism. Smart tourism merupakan pemanfaatan semua potensi yang dimiliki serta sumber daya yang ada guna meningkatkan pengalaman dalam bidang pariwisata. Smart tourism merupakan solusi yang memberikan penawaran berbagai macam bisnis dengan lokasi menyebar sehingga dapat membuka lapangan pekerjaan. Konvergensi konten pariwisata, pelayanan, dan IT dapat membantu para wisatawan untuk memperpanjang batas kognitif dari rencana perjalanan traveling wisatawan dengan detail mengenai sestinasi yang sudah tervisualisasi secara baik. Tujuan utama dari smart tourism yaitu bertitik fokus pada pemenuhan kebutuhan wisatawan dengan menggabungkan perkembangan IT dengan kearipan lokal dan budaya serta inovasi untuk mempromosikan, meningkatkan manajemen pariwisata dan memperbesar skala industri yang lebih luas lagi. Tantangan utama dalam mewujudkan pariwisata berkelanjutan berbasis smart torism adalah memerlukan pemberdayaan masyarakat yang sungguh - sungguh dilakukan oleh, dari, dan untuk masyarakat berpartisipatif timbul sebagai alternatif terhadap pendekatan pembangunan yang serba sentralistik dan bersifat top down. Timbulnya proses partisipasi dalam rangka pemberdayaan masyarakat mendasarkan atas dua perspektif, Pertama; pelibatan masyarakat setempat dalam 
pemilihan, perancangan, perencanaan dan pelaksanaan, program yang akan mewarnai kehidupan masyarakat. Kedua; partisipasi transformasional sebagai tujuan untuk mengubah kondisi lemah dan marjinal menjadi lebih kuat dan mandiri.

Menurut Dra. Dian Kagungan., MH (2019 : 2) Pengembangan sektor pariwisata di Provinsi Lampung antara lain dilakukan dengan mengambil lokasi di Kabupaten Pesawaran. Dalam Rencana Induk Pembangunan Pariwisata Daerah (Ripparda) Kabupaten Pesawaran, Pemerintah Kabupaten Pesawaran menegaskan bahwa Visi pengembangan pariwisata Kabupaten Pesawaran adalah menjadi destinasi wisata unggulan dan berdaya saing tinggi untuk kesejahteraan masyarakat. Potensi pariwisata yang besar untuk dikembangkan di Kabupaten Pesawaran antara lain mulai dari pantai, pegunungan, air terjun, pulau, serta perkebunan yang menarik untuk dikunjungi sebagai tujuan wisata. Desa wisata merupakan pengembangan sebuah desa yang mempunyai potensi wisata serta dilengkapi fasilitas pendukung misalnya transportasi, akses jalan menuju desa wisata, penginapan, kuliner, pusat kerajinan tangan, pusat oleh - oleh. Selain itu, alam serta lingkungan pedesaan yang masih asli serta terjaga dengan baik merupakan faktor terpenting dari wilayah desa wisata. Dengan desa wisata, semua aktifitas sehari - hari masyarakat dapat menjadi daya tarik wisatawan, sehingga desa wisata tidah harus mengubah wajah desa, akan tetapi harus memperkuat ciri khas yang dimiliki oleh setiap desa, baik ciri khas budaya ataupun ciri khas sumberdaya alamnya.

Desa wisata yang terdapat di Kecamatan Negeri Katon Kabupaten Pesawaran menjadi salah satu alternatif tujuan wisata yang sangat menarik dan dan tidak boleh terlewatkan untuk dikunjungi. Di desa wisata tersebut para pengunjung mendapatkan kesegaran dan kenyamanan yang terpancar dari pemandangan alamnya yang sangat indah. adalah sebuah desa di Kabupaten Pesawaran, kecamatan Negeri katon berada di sebelah utara dari Lomberejo. Jarak Kecamatan Negeri Katon ke pusat pemerintahan Kabupaten Pesawaran adalah $4.00 \mathrm{~km}$. Desa Pujo Rahayu mempunyai luas wilayah 445,75 Ha, dihuni oleh 864 KK. Jumlah keseluruhan penduduk desa Pujo Rahayu adalah 3.185 orang dengan rincian jumlah laki-laki 801 orang dan penduduk perempuan 663 orang dengan kepadatan penduduk mencapai 0.00 jiwa/km2. Jumlah angkatan kerja desa Pujo Rahayu kabupaten pesawaran adalah 1.464 orang, dengan jumlah penduduk bekerja 1.621 orang dan jumlah penduduk tidak bekerja orang. (Badan Pusat Statistik Kabupaten pesawaran, 2020/2021/ data desa)

Menurut Gumelar dalam Zakaria (2014) Komponen utama dari desa wisata dapat dilihat dari keunikan serta kealian suatu desa wisata, letaknya berdampingan dengan keadaan alam yang sangat luar biasa, memiliki kebudayaan yang unik untuk menarik minat pengunjung, serta 
mempunyai potensi yang dapat di kembangkan baik dari sisi sarana maupun prasarana. Sedangkan menurut Prasiasa dalam Zakaria (2014) komponen utama desa wisata ada empat komponen yaitu : 1) partisipasi masyarakat lokal; 2) terdapat sistem norma yang berlaku di desa tersebut; 3) adat istiadat desa setempat dan; 4) kebudayaan desa yang masih asli. Sebuah desa wisata wajib memiliki potensi pariwisata, seni, serta adap kebiasaan warga setempat, lingkungan desa masuk dalam lingkup kawasan pengembangan pariwisata ataupun masuk dalam rute perjalanan yang dijual kepada wisatawan, adanya pengelola, pelatih, serta pelaku seni yang dapat mendukung keberlangsungan pengembangan desa wisata tersebut, aksebilitas yang dapat mendukung desa wisata, terjaminnya keamanan, ketertiban serta kebersihan lingkungan desa wisata.

Menurut Gajdosik (2018) dalam Fauziah Hanum, Dadang Suganda, dkk (2020 : 14) konsep smart torism terlahir melalui pengembangan kajian mengenai hubungan antara teknologi dan bidang pariwisata. Smart Torism menggambarkan situasi terkini mengenai pengembangan dalam bidang pariwisata dan di pengaruhi pesatnya perkembangan teknologi dan informasi. Basis Smart Torism menyatukan usaha - usaha kecil mikro, menjembatani masyarakat desa wisata memperkenalkan pariwisata yang dimiliki kepada pasar global.

Desa Wisata Pujo Rahayu merupakan desa yang berada di Kecamatan Negeri katon, kabupaten pesawaran, terletak di jalan Jl. Lintas Branti Desa Pujo Rahayu, Kecamatan Negeri Katon, Kabupaten Pesawaran, Provinsi Lampung. Desa Wisata Pujo Rahayu memiliki banyak potensi wisata yang sangat menarik dan wajib dikunjungi oleh wisatawan. Desa wisata yang berada cukup dekat dengan perbukitan, menghadirkan panorama alam yang sangat menarik untuk dinikmati sehingga dapat memberikan kesegaran dan ketentraman hati, panorama alam pesawahan dan pepohonan yang rindang serta kejernihan airnya juga rumah-rumah adat seperti sesat dengan halaman yang luas, bisa dipakai media bermain sambil menikmati sejuknya udara serta suasana kearipan lokal desa yang masih sangat alami, khas pedesaan yang menjunjung tinggi nilai - nilai budaya serta adat istiadat yang berlaku.

Menurut Undang - Undang No 6 tahun 2014 tentang desa pemberdayaan masyarakat merupakan upaya mengembangkan kemandirian dan kesejahteraan masyarakat dengan meningkatkan pengetahuan, sikap, keterampilan, perilaku, kemampuan dan kesadaran masyarakat. Menurut Hadiwijoyo (2021 : 28) dalam Dra. Dian Kagungan., MH (2019 : 48) berpendapat pemberdayaan masyarakat menggambarkan suatu proses yang berjalan terus menerus dalam meningkatkan kemampuan dan kemandirian masyarakat serta meningkatkan taraf hidup, dalam proses tersebut masyarakat bersama-sama : Mengidentifikasikan dan mengkaji permasalahan serta 
potensi yang di nmilikinya; Menyusun rencana kegiatan berdasarkan hasil kajian; Mengimplementasikan rencana tersebut; Secara terus menerus mamantau dan mengkaji proses dan hasil kegiatannya (memonitoring dan evaluasi).

Fenomena atau masalah yang terjadi mengenai masih tingginya tingkat penggangguran di kabupaten pesawaran, rendahnya komitmen dan kesadaran masyarakat dalam mendukung kegiatan pariwisata, dan keterbatasan dalam keterampilan dan pengetahuan guna mendukung kegiatan pariwisata, terbatasnya sarana dan prasarana pendukung kebudayaan serta pariwisata, keterbatasan kemampuan sumber daya manusia yang profesional untuk mengelola dan mengembangkan potensi bidang pariwisata, belum tergalinya potensi seni dan budaya di desa Pujo Rahayu secara maksimal..

Artikel ini khusus mengukur dan mengetahui pengaruh pengembangan berupa hasil desa wisata berbasis smart torism melalui pemberdayaan kompetensi masyarakat desa Pujo Rahayu kecamatan pesawaran. Selain itu, akan melihat faktor penghambat dan faktor pendukung pengembangan desa wisata berkonsep smart torism melalui pemberdayaan kompetensi masyarakat desa Pujo Rahayu.

\section{METODE PENELITIAN}

\section{Jenis Penelitian}

Penelitian ini adalah penelitian purposive yang didasarkan atas adanya tujuan tertentu melalui pendekatan kualitatif dengan menggunakan dua sumber data yaitu primer dan sekunder. Penelitian ini dilakukan di Desa Wisata Pujo Rahayu, Kec. Negeri Katon, Kab. Pesawaran

\section{Desain penelitian}

Menurut Umar (2015 : 6) desain penelitian merupakan rencana kerja yang terstruktur dari hubungan antar variabel secara menyeluruh agar hasil penelitiannya dapat memberikan jawaban atas pertanyaan dari penelitian. Desain penelitian tersebut mencakup semua hal yang akan dilakukan dalam penelitian, bermulai dari perumusan masalah hingga analisis hasil akhir penelitian. Proses desain penelitian sebagai berikut : 


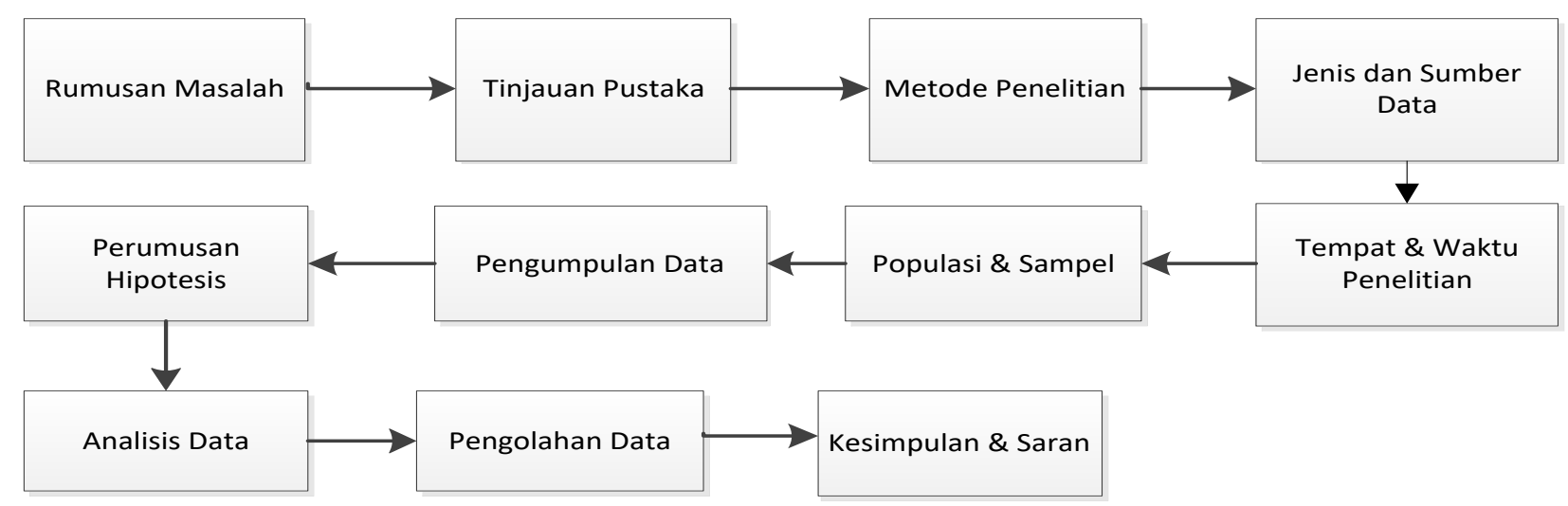

Gambar 1. Skema Desain penelitian

\section{Kerangka Pikir}

Kerangka pikir yang digunakan dalam penelitian ini sebagai berikut :

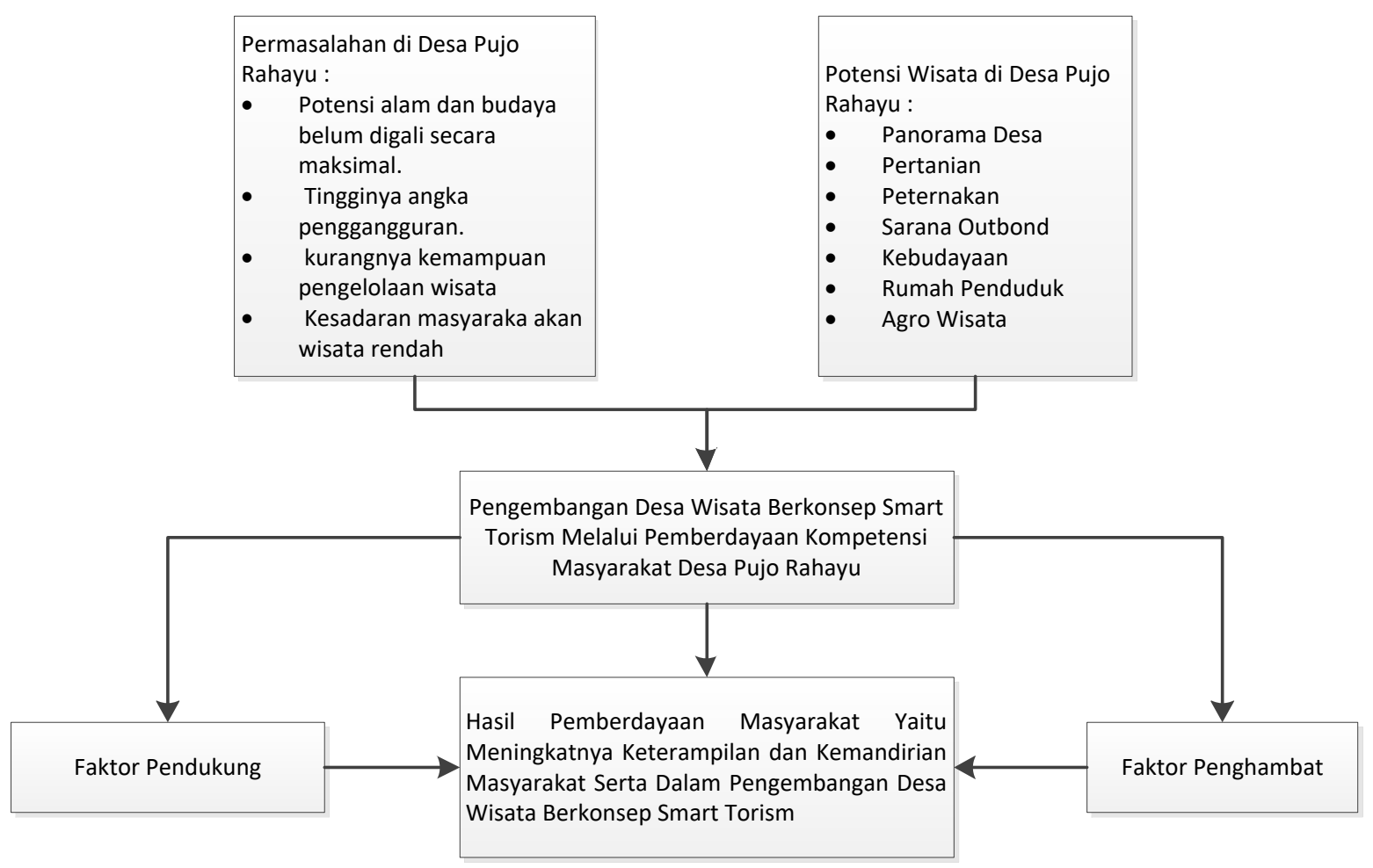

Gambar 2. Skema Kerangka Pikir Penelitian 


\section{Populasi dan Sampel}

Populasi dalam penelitian ini adalah Masyarakat lokal, kelompok sadar wisata dan wisatawan sejumlah 3.616 orang. Penarikan sampel dari populasi guna mewakili populasi dalam penelitian dikarenakan untuk menarik kesimpulan dalam penelitian yang dilakukan pada populasi. Sampel yang digunakan dalam penelitian ini adalah masyarakat lokal, kelompok masyarakat sadar wisata, dan pengunjung/ wisatawan desa wisata Pujorahayu. Menurut Sugiyono (2015 : 81) sampel merupakan sebagian dari jumlah populasi yang dimiliki, jadi sampel dalam penelitian ini sebanyak 98 orang yang terdiri dari masyarakat lokal, kelompok sadar wisata dan wisatawan.

\section{Definisi Operasional}

Berdasarkan Variabel yang diteliti, penulis menyajikan operasional variabel dengan masingmasing indikatornya sebagai berikut :

Tabel 1. Defini operasional Penelitian

\begin{tabular}{|c|c|c|c|c|}
\hline $\begin{array}{c}\text { Variabel } \\
\text { Penelitian }\end{array}$ & Indikator & Definisi & $\begin{array}{l}\text { Alat } \\
\text { Ukur }\end{array}$ & Sumber \\
\hline $\begin{array}{l}\text { Pengembangan } \\
\text { Desa Wisata }\end{array}$ & $\begin{array}{l}\text { Partisipasi } \\
\text { masyarakat } \\
\text { lokal } \\
\text { Terdapat } \\
\text { sistem norma } \\
\text { yang berlaku } \\
\text { Adat istiadat } \\
\text { desa setempat } \\
\text { Kebudayaan } \\
\text { desa yang } \\
\text { masi asli }\end{array}$ & $\begin{array}{l}\text { Desa wisata merupakan pengembangan } \\
\text { sebuah desa yang mempunyai potensi } \\
\text { wisata serta dilengkapi fasilitas } \\
\text { pendukung misalnya transportasi, akses } \\
\text { jalan menuju desa wisata, penginapan, } \\
\text { kuliner, pusat kerajinan tangan, pusat } \\
\text { oleh - oleh. Selain itu, alam serta } \\
\text { lingkungan pedesaan yang masih asli } \\
\text { serta terjaga dengan baik merupakan } \\
\text { faktor terpenting dari wilayah desa } \\
\text { wisata. }\end{array}$ & & $\begin{array}{l}\text { Proceedings. } \\
\text { undip.ac.id }\end{array}$ \\
\hline Smart Torism & $\begin{array}{l}\text { Pelaku Wisata } \\
\text { Atraksi } \\
\text { Transportasi } \\
\text { Fasilitas } \\
\text { penunjang } \\
\text { wisata }\end{array}$ & $\begin{array}{l}\text { Smart Torism adalah suatu transformasi } \\
\text { yang sistematik dan intensif yang } \\
\text { berbasis integrasi generasi baru } \\
\text { Teknologi Informasi dan Komunikasi } \\
\text { (TIK) dengan tujuan memenuhi } \\
\text { kebutuhan pribadi wisatawan, } \\
\text { memperbaiki pengalaman dan kepuasan } \\
\text { wisatawan dalam berwisata, agar dapat } \\
\text { terwujud efektifitas dan optimalitas } \\
\text { sumber daya pariwisata dan sumber daya } \\
\text { sosial. (Zhang 2012) }\end{array}$ & $\begin{array}{l}\text { Teknik } \\
\text { Skoring }\end{array}$ & $\begin{array}{l}\text { https://jurnal. } \\
\text { uns.ac.id/regi } \\
\text { on } \\
\text { Region } \\
\text { Jurnal } \\
\text { Pembanguna } \\
\text { n Wilayah } \\
\text { dan } \\
\text { Perencanaan } \\
\text { Partisipatif }\end{array}$ \\
\hline $\begin{array}{l}\text { Pemberdayaan } \\
\text { kompetensi } \\
\text { Masyarakat }\end{array}$ & $\begin{array}{l}\text { Pemilihan } \\
\text { Lokasi } \\
\text { Sosialisasi } \\
\text { pemberdayaan } \\
\text { Masyarakat } \\
\text { Proses } \\
\text { Pemberdayaan } \\
\text { Masyarakat }\end{array}$ & $\begin{array}{l}\text { Pemberdayaan merupakan suatu aktifitas } \\
\text { untuk menguragi tingkat ketergantungan } \\
\text { dengan tindakan yang dapat } \\
\text { meningkatkan potensi kelompok miskin } \\
\text { untuk mengambil langkah - langkah } \\
\text { politik tanpa kendali guna kemaslahatan } \\
\text { diri pribadi. Moeljarto }(1987: 25)\end{array}$ & & $\begin{array}{l}\text { Moeljarto } \\
(1987: 25)\end{array}$ \\
\hline
\end{tabular}




\section{Teknik Pengumpulan Data}

Menurut sugiyono (2015 : 291) langkah - langkah yang dilakukan dalam penelitian ini adalah 1) Observasi (observation). 2) Kuisioner (Quetionnaires); pengumpulan data penelitian pada kondisi tertentu kemungkinan tidak memerlukan kehadiran peneliti. Pernyataan peneliti dan responden dapat dikemukakan peneliti dan responden dapat dikemukakan secara tertulis melalui kuisioner. Teknik ini memberikan tanggung jawab kepada responden untuk membaca dan menjawab pertanyaan. 3) wawancara (interview) merupakan teknik dalam pengumpulan data dalam metode survey yang menggunakan pertanyaan secara lisan kepada subyek peneliti.

\section{Teknik Analisis Data}

Dalam penelitian ini, metode analisis data yang digunakan adalah Analisis Regresi Linier Berganda. Analisis regresi linier berganda untuk menghitung besarnya pengaruh secara kuantitatif dari suatu perubahan (variavel $\mathrm{X}$ ) terhadap kejadian lainnya (variabel $\mathrm{Y}$ ), maka menggunakan rumus : $\mathrm{Y}=\alpha+\beta 1 \mathrm{X} 1+\beta 2 \mathrm{X} 2+$ et

1. Uji Validitas dan Reabilitas Instrumen

Menurut Sugiyono (2015 : 172) Analisis dilakukan mengkorelasiikan masing-masing skor item dengan skor total. Skor total adalah penjumlahan dari keseluruhan item. Item-item pertanyaan yang berkorelasi signifikan dengan skor total menunjukkan item-item tersebut mampu memberikan dukungan dalam mengungkap apa yang ingin diungkap. Pengujian menggunakan uji dua piihak dengan taraf signifikansi 0,05. Menurut Siswoyo Haryono dan Parwoto Wardoyo (2013:74) uji reability adalah ukuran internal consistency indikator suatu konstruk. Hasil reabilitas yang tinggi memberikan keyakinan bahwa indikator individu semua konsisten dengan pengukurannya. Tingkat reabilitas yang diterima secara umum adalah $>0.70$ sedangkan reabilitas $<0.70$ dapat diterima untuk penelitian yang bersifat eksploratory.

2. Uji Asumsi Klasik, Terdiri dari : 1) Uji Normalitas, 2) Uji Heterokedasitas, 3) Uji multikolinieritas, 4) Uji Autokorelasi

3. Uji Hipotesis, pengujian hipotesis pada penelitian ini menggunakan analisis regresi linier berganda. Analisis ini digunakan untuk mengetahui pengaruh beberapa variabel independen (X) terhadap variabel dependen (Y). Analisis linier berganda dilakukan dengan uji koefisien determinasi, uji $\mathrm{R}^{2}$, Uji $\mathrm{F}$ dan uji $\mathrm{T}$. Model regresi dalam penelitian ini adalah : $\mathrm{Y}=\alpha+\beta 1 \mathrm{X} 1+$ $\beta 2 \mathrm{X} 2+$ et

4. Uji Koefisien Determinasi $\left(\mathrm{R}^{2}\right)$ digunakan untuk mengukur seberapa jauh kemampuan model dalam menerangkan variasi variabel dependen (Ghozali:2011) Dari koefisiensi determinasi ini (R) dapat diperoleh suatu nilai untuk mengukur besarnya sumbangan dari beberapa variabel X 
terhadap variasi naik turunnya variabel Y. Nilai R2 yang kecil berarti kemampuan variabelvariabel independen dalam menjelaskan variabel dependen amat terbatas.

5. Uji Statistik F, apabila nilai $F$ hitung lebih besar daripada $F$ tabel, maka dapat dikatakan bahwa semua variabel independen secara bersama-sama mempengaruhi variabel dependen. Menentukan $\mathrm{F}$ tabel dan $\mathrm{F}$ hitung.

6. Uji Statistik t, digunakan dalam penelitian ini untuk menguji variabel bebas secara satu persatu ada atau tidaknya pengaruh terhadap variabel terikat (Y). Jika $\mathrm{t}$ hitung $>\mathrm{t}$ tabel, maka menyatakan bahwa suatu variabel independen secara individual mempengaruhi variabel dependen (Ghozali, 2011).

\section{HASIL DAN PEMBAHASAN}

Provinsi Lampung merupakan salah satu provinsi di Indonesia memiliki potensi besar di bidang pariwisata. Hal ini terbukti dari besarnya animo wisatawan khususnya wisatawan manca negara untuk berkunjung ke Provinsi Lampung. Dalam lima tahun terakhir, kunjungan wisatawan mancanegara mengalami pertumbuhan sekitar tujuh kali lipat. Menurut Dra. Dian Kagungan., MH (2019 : 2) Pengembangan sektor pariwisata di Provinsi Lampung antara lain dilakukan dengan mengambil lokasi di Kabupaten Pesawaran. Dalam Rencana Induk Pembangunan Pariwisata Daerah (Ripparda) Kabupaten Pesawaran, Pemerintah Kabupaten Pesawaran menegaskan bahwa Visi pengembangan pariwisata Kabupaten Pesawaran adalah menjadi destinasi wisata unggulan dan berdaya saing tinggi untuk kesejahteraan masyarakat. Potensi pariwisata yang besar untuk dikembangkan di Kabupaten Pesawaran antara lain mulai dari pantai, pegunungan, air terjun, pulau, serta perkebunan yang menarik untuk dikunjungi sebagai tujuan wisata

Menurut Gumelar dalam Zakaria (2014) Komponen utama dari desa wisata dapat dilihat dari keunikan serta kealian suatu desa wisata, letaknya berdampingan dengan keadaan alam yang sangat luar biasa, memiliki kebudayaan yang unik untuk menarik minat pengunjung, serta mempunyai potensi yang dapat di kembangkan baik dari sisi sarana maupun prasarana. Sedangkan menurut Prasiasa dalam Zakaria (2014) komponen utama desa wisata ada empat komponen yaitu : 1) partisipasi masyarakat lokal; 2) terdapat sistem norma yang berlaku di desa tersebut; 3) adat istiadat desa setempat dan; 4) kebudayaan desa yang masih asli. Sebuah desa wisata wajib memiliki potensi pariwisata, seni, serta adap kebiasaan warga setempat, lingkungan desa masuk dalam lingkup kawasan pengembangan pariwisata ataupun masuk dalam rute perjalanan yang dijual kepada wisatawan, adanya pengelola, pelatih, serta pelaku seni yang dapat mendukung 
keberlangsungan pengembangan desa wisata tersebut, aksebilitas yang dapat mendukung desa wisata, terjaminnya keamanan, ketertiban serta kebersihan lingkungan desa wisata.

Smart tourism merupakan tahapan terbaru dari pengembangan pariwisata yang dipengaruhi dari evolusi dari perkembangan teknologi dan informasi.Menurut Gajdosik (2018) dalam Fauziah Hanum, Dadang Suganda, dkk (2020 : 14) konsep smart torism terlahir melalui pengembangan kajian mengenai hubungan antara teknologi dan bidang pariwisata. Smart Torism menggambarkan situasi terkini mengenai pengembangan dalam bidang pariwisata dan di pengaruhi pesatnya perkembangan teknologi dan informasi. Basis Smart Torism menyatukan usaha - usaha kecil mikro, menjembatani masyarakat desa wisata memperkenalkan pariwisata yang dimiliki kepada pasar global. Menurut Piu Liu dan Yuan Liu (2016) dalam Azrina Farania dkk (2017 : 38) mengatakan smart torism atau yang di kenal sebagai pariwisata cerdas sangat kuat berkaitan dengan kota cerdas atau smart city, dikarenakan smart torism muncul dari konsep kota cerdas dan sangat tergantung terhadap imprastruktur dan memperkuat kontribusi setiap sub-sistem pada smart city serta keterkaitan antar sistem smart city mampu memperkaya konsep smart city. Menurut Zhang (2012) dalam Azrina Farania dkk (2017 : 39) Smart torism merupakan perubahan yang terstruktur dan intensif yang menjadi rujukan integrasi generasi baru teknologi informasi dan komunikasi. Dengan tujuan memenuhi kebutuhan wisatawan, menyempurnakan pengalaman dan kepuasan wisatawan selama berlibur, sehingga dapat terwujud efektifitas, dan optimalisasi sumber daya sosial.

Menurut Undang-Undang No 6 tahun 2014 tentang desa pemberdayaan masyarakat merupakan upaya mengembangkan kemandirian dan kesejahteraan masyarakat dengan meningkatkan pengetahuan, sikap, keterampilan, perilaku, kemampuan dan kesadaran masyarakat. Menurut Hadiwijoyo (2021 : 28) dalam Dra. Dian Kagungan., MH (2019 : 48) berpendapat pemberdayaan masyarakat menggambarkan suatu proses yang berjalan terus menerus dalam meningkatkan kemampuan dan kemandirian masyarakat serta meningkatkan taraf hidup, dalam proses tersebut masyarakat bersama-sama, yaitu Mengidentifikasikan dan mengkaji permasalahan serta potensi yang di nmilikinya; Menyusun rencana kegiatan berdasarkan hasil kajian; Mengimplementasikan rencana tersebut; Secara terus menerus mamantau dan mengkaji proses dan hasil kegiatannya (memonitoring dan evaluasi).

Prinsip-prinsip pemberdayaan menurut Agus Tri Cahyono (2008:11-12) adalah Pembanguna yang dilakukan wajib bersifat lokal; Lebih mengutamakan aktifitas sosial; Menggunakan strategi organisasi komunitas atau sosial lokal; Terdapat kesamaan kedududkan 
dalam hubungan kerja; Menggunakan strategi partisipasi, seluruh anggota kelompok sebagai subjek; Usaha kesejahteraan sosial guna keadilan

Tujuan utama dalam pemberdayaan masyarakat yang ingin dicapai adalah untuk membentuk individu dan masyarakat menjadi mandiri. Kemandirian tersebut yaitu kebebasan berfikir, melakukan tindakan serta mengendalikan tindakan yang telah mereka lakukan tersebut. Kemandirian masyarakat yaitu dimana suatu keadaan yang di alami masyarakat yang ditandai dengan kemampuan guna memikirkan sesuatu, mengambil keputusan dan melakukan suatuhal yang dipandang tepat guna mencapai pemecahan masalah - masalah yang di hadapi dengan memanfaatkan daya dan kemampuan yang dimiliki, terdiri dari kemampuan psikologis, konatif, psikomotororik, pengorganisasian sumber daya yang dimiliki oleh organisasi internal masyarakat, dari itu guna mencapai kemandirian memerlukan dukungan kemampuan berupa sumber daya manusia yang utuh dengan kondisi kognitif, konatif, psikomotorik dan efektif, serta sumber daya lainnya sarana dan prasarana.

Dari angket beserta kuesioner yang disebarkan pada masyarakat lokal, kelompok ssadar wisata, dan wisatawan yang mengisi kuesioner dalam penelitian ini maka didapat kenyataan yang ditemui dilapangan, menunjukkan bahwa Pengembangan desa wisata masih harus ditiingkatkan lagi. Karena masih adanya keluhan dan kritikan dari wisatawan tentang pasilitas di tempat wisata, data base sebagai basis dalam Smart Tourism masih belum tertata dengan baik, karena masih belum terdapat update pengembangan desa wisata, dan juga dalam melakukan pemberdayaan kompetensi masyarakat masih belum maksimal. Masih banyak masyarakat yang kurang peduli terhadap pemberdayaan kompetensi yang dilakukan oleh aparatur desa untuk masyarakat.

Wisatawan yang berwisata di desa wisata Pujo rahayu berpersepsi pengembangan desa wisata berkonsep smart tourism melalui pemberdayaan kompetensi masyarakat masih dianggap kurang karena di dapati nilai koefisien korelasi yang menunjukkan tingkat hubungan antara variabel sebesar 0,737, yang berarti berpengaruh positif antar variabel. Sedangkan koefisien determinasi yang menunjukkan tingkat pengaruh sebesar 0,533hal ini menjelaskan bahwa variabel Pemberdayaan kompetensi Masyarakat (Y) di pengaruhi oleh variabel Pengembangan desa Wisata (X1) dan Smart tourism (X2) sebesar 0,543 atau sebesar 54,3\% dan sisanya $(1-0,54)=0,46$ atau $46 \%$ di pengaruhi oleh variabel lain yang diteliti.

\section{KESIMPULAN}

Kesimpulan peneltian ini merupakan hasil penyelidikan yaitu Pengembangan Desa Wisata Berbasis Smart Tourism secara parsial maupun simultan mempunyai pengaruh yang signifikan 
terhadap Pemberdayaan Kompetensi masyarakat desa Wisata Pujo Rahayu. Berdasarkan hasil uji koefisien determinasi (R2), maka diperoleh nilai koefisien determinasi sebesar 0,533 (55\%). Hal ini berarti bahwa variabel Pengembangan Desa Wisata Berbasis Smart Tourism menjelaskan pengaruhnya terhadap Pemberdayaan Kompetensi Masyarakat Desa Wisata Pujo Rahayu sebesar $55 \%$, sedangkan sisanya $45 \%$ merupakan variabel lain diluar model.

Sedangkan, implikasi peneltian ini berupa wisatawan merasa pengembangan desa wisata Pujo Rahayu masih belum maksimal hal ini terlihat dari belum tersentalnya tempat wisata yang dimiliki oleh desa wisata Pujo Rahayu, wisatawan masih merasa bahwa tempat wisata yang dimiliki oleh desa wisata Pujo Rahayu masih kurang terawat, petunjuk jalan menuju tempat wisata masih belum banyak jadi wisatawan harus bertanya, hanya memiliki pintu gapura saja yg menuju arah masuknya, wisatawan dan masyarakat lokal merasa bahwa pemberdayaa kompetensi masyarakat masih belum terlaksana dengan baik, hal ini terlihat dari masih banyaknya masyarakat yang belum memiliki kreatifitas guna meningkatkan minat wisatawan untuk berkunjung. Serta belum terpeliharanya pasilitas umum di tempat wisata desa Pujo Rahayu.

Saran yang kiranya dapat bermanfaat bagi Desa Wisata Pujo Rahayu kec. Negeri Katon, Kab. Pesawaran, khususnya bagi pengelola desa wisata Pujo Rahayu yaitu :

1. Hendaknya pengelola tempat wisata di desa wisata Pujorahayu Kec. Negeri katon, kab. Pesawaran lebih menjaga pasilitas yang telah dimilikinya agar wisatawan lebih merasa nyaman pada saat berwisata.

2. Petunjuk arah menuju tempat wisata dewa wisata Pujo rahayu hendaknya di perbanyak agar wisatawan yang ingin berkunjung tidak merasa binggung menuju tempat wisata yang ada di desa wisata Pujorahayu.

3. Pemberdayaan kompetensi masyarakat sekitar hendaknya lebih di tingkatkan lagi dengan memberikan pelatihan sehingga masyarakat sekitar lebih kreatif lagi.

4. Desa wisata Pujo Rahayu hendaknya memahami keinginan wisatawan dan selalu update tempat - tempat bersua fhoto yang instagram mebel.

5. Masyarakat sekitar hendaknya mendapatkan pelatihan dalam meningkatkan skill guna menjadi salah satu destinasi tujuan wisata di desa wisata Pujo Rahayu.

6. Pengelola di tempat wisata hendaknya diberi pelatihan bagaimana cara mengelola tempat wisata yang bai, agar pengelolaan lebih baik lagi. 


\section{DAFTAR PUSTAKA}

Dra. Dian Kagungan, MH (2019) Kebijakan Penata Kelolaan Pariwisata di Daerah Otonom Baru. Bandar Lampung, Pustaka Media.

Sugiyono (2015) Metode Penelitian Manajemen. Bandung : Alfabeta

Undang-Undang No 6Tahun 2014, Tentang Desa. Peraturan Pemerintah No 43Tahun 2014Tentang Peraturan Pelaksanaan undang-undang No. 6 Tahun 2014 tentang Desa

Profile desa pujo rahayu Kec. Negeri Katon, Kab. Pesawaran tahun 2020, dilihat pada tanggal 01 Desember 2020.

Undang-Undang No 6Tahun 2014, Tentang Desa. Peraturan Pemerintah No 43Tahun 2014Tentang Peraturan Pelaksanaan undang-undang No. 6 Tahun 2014 tentang Desa

Totok Mardikanto dan Poerwoko Soebianto. 2013. Pemberdayaan Masyarakat Dalam Perspektif Kebijakan Publik. rev.ed. Bandung: Alfabeta.

Manahati Zebua. 2016. Inspirasi Pengembangan Pariwisata. Yogyakarta: depublish.

Gajdosik, Tomas. 2018. Smart Tourism: Concepts and Insights from Central Europe. Czech Journal of Tourism.Vol 1.

Fandeli, C. (2002). Perencanaan Kepariwisataan Alam. Fakultas Kehutanan Universitas Gadjah Mada, Bulaksumur, Yogyakarta.

Zakaria, F. \& Suprihardjo, R.D. (2014). Konsep Pengembangan Kawasan Desa Wisata di Desa Bandungan Kecamatan Pakong Kabuapaten Pamekasan. Jurnal Teknik Pomits Vol. 3 No. 2, hal. 245-249

Lopez de Avila, A. (2015). Smart Destinations: XXI Century Tourism. Presented at the ENTER2015 Conference on Information and Communication Technologies in Tourism, Lugano, Switzerland

Alex Winarno dan Yoga Perdana, 2015, 'The Effecs of Competence andMotivation on Employee Performance at PT Pos Indonesia BandungCilaki Head Office',Journal Conference on Business, Marketing, andInformation System Management, hh. 1-5, dilihat 24 November 2020,<http://icehm.org/upload/2512ED1115030.pdf>.

Fauziah Hanum, Dadang Suganda, Eng. Budi Muljana, Cipta Endyana, Heryadi Rachmat 2020. Konsep Smart Tourism Sebagai implementasi Digitalisasi di Bidang Pariwisata. TORNAREJournal Of Sustainable Tourism Reserch. Volume 3 No. 1, Mei 2020, dilihat pada tanggal 01 November 2020.

Hendry Ferdiansyah, Cipta Endyana, Heryadi Rachmat, Ute Lies Siti Khadijah 2020. Pengembangan Pariwisata Halal di Indonesia Melalui Konsep Smart Tourism. TORNAREJournal Of Sustainable Tourism Reserch. Volume 2, No. 1, Januari 2020, dilihat pada tanggal 04 November 2020.

I W. Pantiyasa, 2019, Kontruksi Model Pengembangan Desa Wisata Menuju Smart Eco-Tourism di Desa Paksebali, Klungkung Bali, Jurnal Kajian Bali Volume 09, No. 01, April 2019, dilihat pada tanggal 06 November 2020

Azrina Farania, Ana Hardiana, Rufia Andisetyana Putri 2017, Kesiapan Kota Surakarta Dalam Mewujudkan Pariwisata Cerdas (Smart Tourism) Ditinjau Dari Aspek Fasilitas dan Sistem Pelayanan. Region Volume 12 No. 1 Januari 2017, dilihat pada 06 November 2020

Christne N. Lumenta, Michael S. Mantiri, Donald K. Monintja 2019, Pengelolaan Objek Wisata Pantai Pulisan di Desa Pulisan Kecamatan Likupang Timur Minahasa Utara. EKSEKUTIFJurnal Jurusan Ilmu Pemerintahan Volume 3 No. 3 Tahun 2019, dilihat pada tanggal 07 November 2020.

Andree E. Widjaja, Hery dan Riswan E Taringan 2016, Meningkatkan Potensi Pariwisata Danau Toba Melalui Konsep Smart Tourism : Aplikasi dan Tantangannya. SNITI-3 Prosiding Seminar Nasional Inovasi dan Teknologi Informasi November 2016, dilihat pada tanggal 15 November 2020. 